\title{
Callus induction and axillary shoot formation in Asparagus racemosus Willd.
}

\author{
Neelofer Nabi, ${ }^{1,2}$, Seema Singh', Peer Saffeullah"* \\ 'Department of Botany, University of Kashmir, Srinagar, J\&K-190006, India, '2Department of Botany, Jamia Hamdard, \\ New Delhi-110062, India
}

\section{Received: December 14, 2019 \\ Revised: August 27, 2020 \\ Accepted: August 29, 2020 \\ Published: September 05, 202 \\ *Corresponding Author: \\ Peer Saffeullah \\ Email: psaffeullah.139@gmail. \\ com}

\section{ABSTRACT}

An experiment was performed to establish a regeneration protocol for an important medicinal plant, Asparagus racemosus In the present investigation, nodal and internodal explants were employed for callus induction and axillary shoot formation. Maximum callus induction frequency was found on MS medium fortified with 2,4-D (1.0 mg/L) along with NAA (1.0 $\mathrm{mg} / \mathrm{L})$ and BAP $(0.5 \mathrm{mg} / \mathrm{L})$. However, individual effects of 2,4-D or NAA with BAP showed least callus induction. The higher concentrations of 2,4-D and BAP decreased the response of explants. However, maximum axillary shoot formation was observed on MS medium adjuvanted with BAP $(2.0 \mathrm{mg} / \mathrm{L})$ and NAA $(0.5 \mathrm{mg} / \mathrm{L})$.

KEYWORDS: 2,4-D, Asparagus, BAP, callus induction, NAA, shoot formation

\section{INTRODUCTION}

Plants have been used invariably by humans since ages for food, medicines and various other day to day needs. However, increasing population and incessant human needs have put enormous pressure on these bio-resources and lead to their unprecedented depletion from nature. To address this problem, the tissue culture techniques have come to the rescue of depleting plants [1]. Plant tissue culture has been extensively used to boost the large scale micro-propagation of threatened medicinal plants [2]. This not only helps in large scale production of true-to-type plantlets but also helps to conserve rare and threatened plants.

Asparagus racemosus (Asparagaceae), commonly known as shatavari, is an important medicinal plant which is recognized as 'vulnerable' mainly due to its destructive harvesting [3]. Being a woody climber, it grows in tropical and sub- tropical areas in India. It can be seen at an altitude of $1500 \mathrm{~m}$. It reaches up to a height of 1-2 m, commonly along rocky and gravelly soils. Its botany consists of green leaves called phylloclades. The white flowers are transformed into blackish purple berries. The fruit berries contain seeds. These seeds are the main propagules of A. racemosus. Howbeit, vegetative reproduction is slow process in case of A. racemosus. It has large medicinal value especially concerned with female medication including phytoestrogen properties and is extensively used in combating menopausal symptoms and to increase milk production [4,5]. The abundant active compounds found in A. racemosus are Shatavarin (I-IV), Shatavaroside A and Shatavaroside B, Filliasparoside $\mathrm{C}$ which are steroidal saponins. Asparagamine A is an alkaloid found in roots of A. racemosus. Some flavonoids and essential fatty acids have also been reported in A. racemosus. In Ayurveda, A. racemosus is referred to as queen of herbs because it is used in more than 60 formulations of ayurvedic medicines, mostly the medicines are concerned with female medication. In natural habitat this plant is declared as vulnerable because of destructive harvesting for active compounds.

It mostly proliferates through seeds but can also propagate through vegetative methods, but this process is slow. So, the in vitro techniques provide a better way for propagation and conservation of A. racemosus, a medicinally important and vulnerable plant. So, the present investigation was aimed to design an enhanced protocol for callus induction and axillary shoot formation in nodal and internodal explants of A. racemosus.

\section{MATERIALS AND METHODS}

Nodal and internodal explants of Asparagus racemosus Willd. were taken from herbal garden of Jamia Hamdard and were used as experimental material for callus induction and axillary shoot formation. These explants were collected in self-sealing polybags.

Copyright: @ The authors. This article is open access and licensed under the terms of the Creative Commons Attribution License (http:// creativecommons.org/licenses/by/4.o/) which permits unrestricted, use, distribution and reproduction in any medium, or format for any purpose, even commercially provided the work is properly cited. Attribution - You must give appropriate credit, provide a link to the license, and indicate if changes were made. 


\section{Explant Sterilization}

The nodal and internodal segments of A. racemosus were placed in a beaker under running tap water for about $30 \mathrm{~min}$. Two to three pinches of cetrinide were added to beaker containing explants to clean the explants properly. Now the explants were washed properly to remove any traces of detergent. Then the explants were shifted to laminar hood and the explants were treated with $70 \%$ alcohol for about $30 \mathrm{~min}$. and then washed thrice with distilled water under sterile conditions. The tissue was now submerged in a beaker containing $0.15 \%$ mercuric chloride $\left(\mathrm{HgCl}_{2}\right)$ for $\mathrm{l}$ min. After that, the $\mathrm{HgCl}_{2}$ was removed by washing (3 times) with distilled water under aseptic conditions.

\section{Medium and Culture}

The media used in this experiment was Murashige and Skoog [6] media. The medium contains inorganic nutrients, organic, vitamins and sucrose. Various plant growth regulators (PGR's) like 2,4-Dichlorophenoxyacetic acid (2,4-D), 1-Napthalenacetic acid (NAA) and 6-Benzylaminopurine (BAP) were used in this experiment using different concentrations.

\section{Statistical Analysis}

Data represents mean \pm standard deviation (SD). Values are means of three replicates and the presented mean values were analyzed by SPSS software (version 22) for one-way ANOVA. Significant differences were estimated using Duncan's Multiple Range Test (DMRT) at $p<0.05$.

\section{RESULTS}

\section{Callus Induction}

After inoculations of explants, tubes were exposed to a photo period 16h of light and $8 \mathrm{~h}$ of darkness at $25 \pm 2^{\circ} \mathrm{C}$ and subcultured at regular intervals of four weeks of incubation in culture room. The cumulative effect of 2,4-D $(1.0 \mathrm{mg} / \mathrm{L}), \mathrm{NAA}(1.0 \mathrm{mg} / \mathrm{L})$ and BAP $(0.5 \mathrm{mg} / \mathrm{L})$ resulted in maximum callus induction frequency of $40 \%$ in nodal explants after 4 weeks of incubation period (Figure 1; Figure 2). The higher the concentrations of 2,4-D and BAP decreased the response of the explants. It was also observed that the individual effects of 2,4-D or NAA with BAP shows least callus induction response of $10 \%$ (Table 1).

\section{Axillary Shoot Formation}

The commencement of multiple shoot clumps from nodal explants shows shoot forming response to different combinations and concentrations of growth regulators. Initiation of shoots clumps was observed in cultures grown on various combination of BAP either alone or adjuvanted with NAA within four weeks of inoculation (Figure 3-5). However maximum shoot formation was observed on MS medium supplemented with $2.0 \mathrm{mg} / \mathrm{L}$ BAP and $0.5 \mathrm{mg} / \mathrm{L} \mathrm{NAA}$ resulting in mean no. of 3 shoots per node (Table 2). In the absence of NAA, the induction frequency of BAP decreased, compared to combination. As the BAP concentration intensified above $2.0 \mathrm{mg} / \mathrm{L}$, the induction ability reduced.

\section{DISCUSSION}

As the A. racemosus is medicinally important plant and a vulnerable plant also. Plant tissue culture provides an effective way for conservation and micropropagation of A. racemosus.

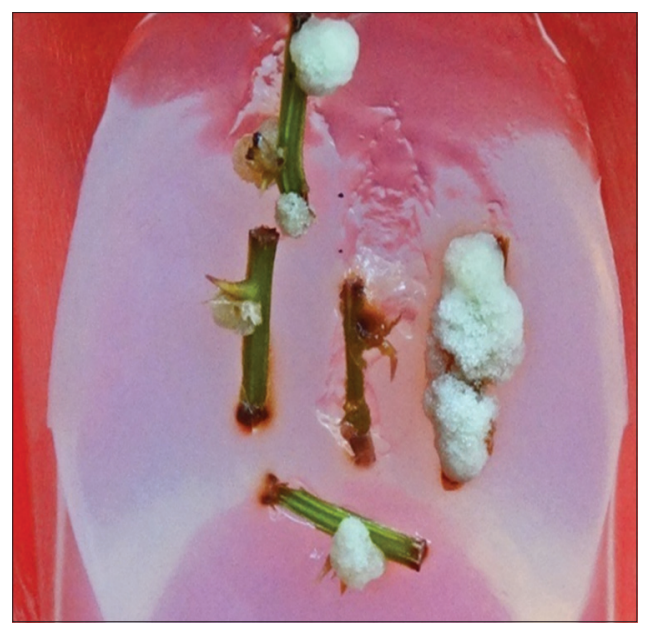

Figure 1: Callus induced on nodal explants of Asparagus racemosus inoculated on MS medium supplemented with 2,4-D, BAP, NAA

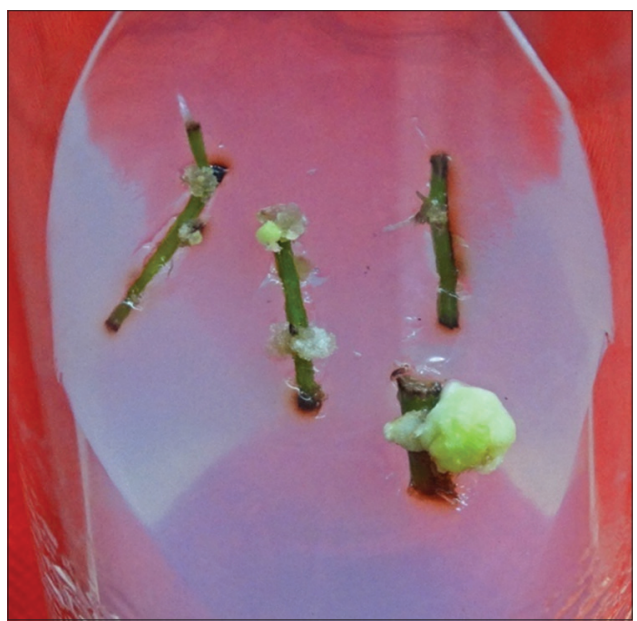

Figure 2: Callus induced on nodal segments placed vertically in MS medium having 2,4-D and BAP

Table 1: Callus induction frequency of nodal explants of $A$. racemosus when incubated in different concentrations of 2,4-D, NAA and BAP $(\mathrm{mg} / \mathrm{L})$, after 4 weeks

\begin{tabular}{lcccc}
\hline $2,4-D^{\psi}$ & NAA $^{\psi}$ & BAP $^{\psi}$ & Callus induction (\%) & Fresh weight (g) \\
\hline 1 & - & 0.5 & 10 & $0.10 \pm 0.04^{\mathrm{a}}$ \\
- & 1 & 0.5 & 10 & $0.12 \pm 0.07^{\mathrm{a}}$ \\
1 & 1 & 0.5 & 40 & $0.28 \pm 0.03^{\mathrm{c}}$ \\
2 & 1 & 0.5 & 30 & $0.23 \pm 0.05^{\mathrm{c}}$ \\
1 & 2 & 0.5 & 30 & $0.20 \pm 0.07^{\mathrm{c}}$ \\
2 & 2 & 0.5 & 20 & $0.15 \pm 0.06^{\mathrm{b}}$ \\
\hline
\end{tabular}

\% 2,4-D: 2,4-Dichlorophenoxyacetic acid; NAA: 1-Napthalenacetic acid; BAP: 6-Benzylaminopurine ${ }^{*}$ Data $($ mean \pm SD) followed by dissimilar lowercase letters are significantly different at $p<0.05$ by DMRT 


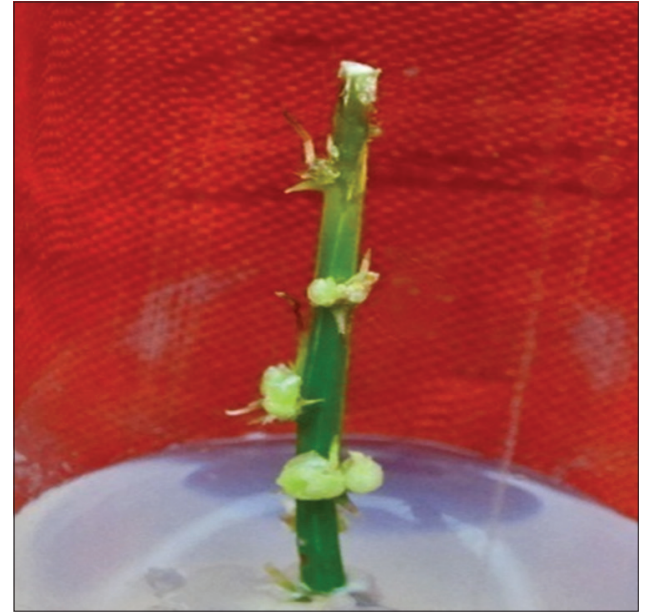

Figure 3: Axillary shoots induction from nodes on BAP $(1.0 \mathrm{mg} / \mathrm{L})$ and NAA (0.5 mg/L) added MS medium

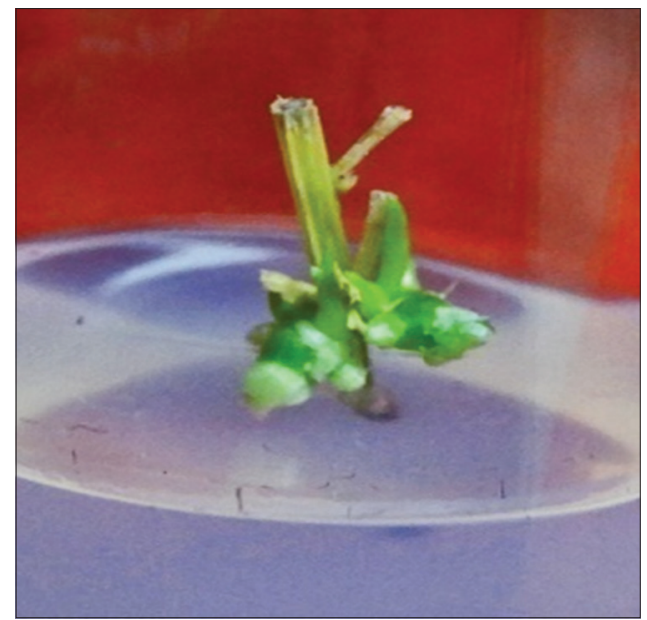

Figure 4: Multiple shoot clumps emerging out from nodal portion on $2.0 \mathrm{mg} / \mathrm{L} \mathrm{BAP}$ and $0.5 \mathrm{mg} / \mathrm{L} \mathrm{NAA}$

Our main aim was to develop an efficient protocol for callus and axillary shoot formation, so that the in vitro techniques provide a way to its propagation and commercial utilization of its active compounds. In present study it was found that combination of auxins and cytokinins showed the best result as compared with either single dose of auxin or cytokinin.

In the present study, callus induction and proliferation from nodal explants of $A$. racemosus was evaluated under the influence of 2,4-D, NAA, BAP amended MS medium. Combinations of auxins and cytokinins have shown high callus induction frequency and growth of callus from nodal explants as compared to either single auxin in high concentration or combination of auxins. Plants are known to behave differently to cultural conditions depending on PGR combinations used and the genotype of the plant species. Previous studies on A. racemosus reveal that NAA, and 2,4-D show successful callus induction with low concentrations of BAP in MS medium [7]. Borjian and Arak [8] also observed maximum callus induction in MS medium when lower concentrations of BAP

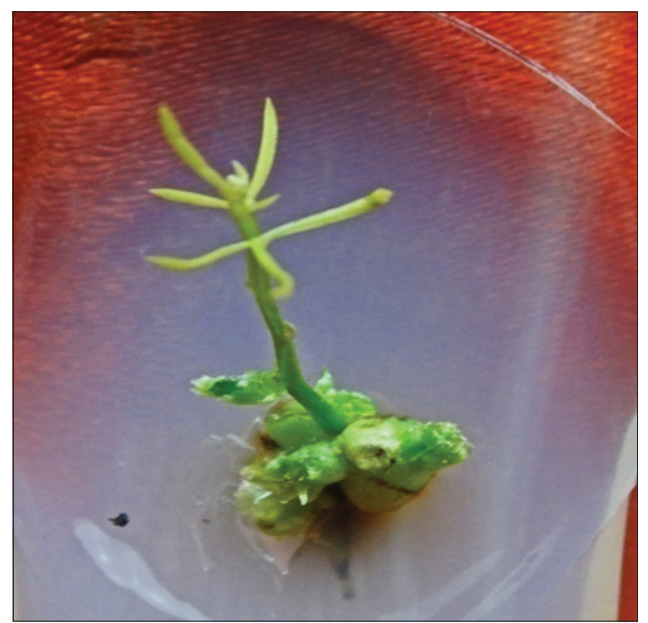

Figure 5: Axillary shoot obtained on MS medium supplemented with $3.0 \mathrm{mg} / \mathrm{L}$ BAP and $0.5 \mathrm{mg} / \mathrm{L} \mathrm{NAA}$

Table 2: Shoot induction frequency from nodal explants on BAP and NAA (mg/L) amended on MS medium after 4 weeks of incubation

\begin{tabular}{lccc}
\hline BAP $\psi$ & NAA $\psi$ & Shoot induction $\%$ & No. of shoots induced /node \\
\hline 1 & - & - & - \\
1 & 0.5 & 10 & 1 \\
2 & - & 30 & 1 \\
2 & 0.5 & 40 & 3 \\
3 & - & 10 & 1 \\
3 & 0.5 & 30 & 2 \\
4 & - & 10 & 1 \\
4 & 0.5 & 10 & 1 \\
\hline
\end{tabular}

\% BAP: 6-Benzylaminopurine; NAA: 1-Napthalenacetic acid

was supplemented along with NAA and 2,4 -D combination in Brassica napus. Most monocots are showing recalcitrance to tissue culture conditions due to the absence of secondary growth. Monocots show meager response and take long time for initiation of callus [9]. It is reported that in various monocot species such as Allium sativum, the induction and proliferation of callus is challenging and sluggish and somehow tough to maintain [10]. For shoot induction $0.1 \mathrm{mg} / \mathrm{L} \mathrm{NAA}$ and $0.5 \mathrm{mg} / \mathrm{L}$ $\mathrm{BAP}$ was found to be most effective. In bud formation, the trend was found to be just opposite to callus induction i.e., increase in BAP concentration showed increase in the number of buds per explants until the NAA concentration was limited. Direct shoot regeneration from nodes of Phalaenopsis orchids using different concentrations of BAP and NAA was reported by Polonca et al. [11]. The maximum regeneration was obtained in medium supplemented with lower concentration of NAA and higher concentration of BAP. Similar results were obtained by Sharan et al. [12]. Dharmendra et al. [13] revealed that shoot multiplication required BAP and was found to be more effective than kinetin in Oxystelma secamone. This synergistic outcome of BAP and NAA has also been established in Santolina canescens [14] and in Bupleurum fruticosom [15]. Propagation of $A$. racemosus from callus culture on medium containing IAA and BAP has been reported [16], but it was not found to be very effective in the present work. We observed that combination of 
BAP and NAA was needed for better axillary shoot induction. Cheetam et al. [17] reported Shoot tip culture of Asparagus officinalis on medium containing kinetin and NAA; however, in the present work, kinetin along with NAA was found inefficient for shoot growth in Asparagus racemosus. Similarly, BAP plays a part in shoot and bud induction, although combinations of NAA and BAP at different levels where found to be effective in almost all cases.

\section{CONCLUSION}

Different plants behave differently to cultural conditions depending on the plant growth regulators, genotype of the plant. The callus induction was higher at $1.0 \mathrm{mg} / \mathrm{L} \mathrm{2,4-D,} 1.0 \mathrm{mg} / \mathrm{L}$ NAA, $0.5 \mathrm{mg} / \mathrm{L} \mathrm{BAP}$ with $40 \%$ callus formation. Percentage of shoot induction was higher at $2.0 \mathrm{mg} / \mathrm{L}$ BAP and $0.5 \mathrm{mg} / \mathrm{L} \mathrm{NAA}$ in this study of shoot induction in A. racemosus. So we can conclude that in case of A. racemosus callus induction was best using two different auxins and a cytokinin while as the shoot induction showed its best results with combination of auxin and cytokinin.

\section{ACKNOWLEDGEMENT}

The first author is highly thankful to the Department of Botany, Jamia Hamdard for providing all the facilities for conducting this research.

\section{CONFLICT OF INTEREST}

The authors declare that they have no conflict of interest to declare.

\section{REFERENCES}

1. Stajner N. Micropropagation of Asparagus by in vitro shoot culture. In: Lambardi M. et al. (eds.), Protocols for micropropagation of selected economically important horticultural plants, Methods in Molecular biology. vol. 994. New York: Springer; 2013.
2. Lomrar $\mathrm{R}$, Jat $\mathrm{BL}$, Yadav $\mathrm{BL}$. In vitro conservation of medicinal plant (Asparagus racemosus). Journal of Pharmacognosy and Phytochemistry. 2018;7(1):1818-1822.

3. Bopana N, Saxena S. In vitro propagation of a high value medicinal plant: Asparagus racemosus Wild. In Vitro Cellular \& Developmental Biology. 2008;44(6):525-532.

4. Sabnis PB, Gaitonde BB, Jetmalani M. Effects of alcoholic extracts of Asparagus racemosus on mammary glands of rats. Indian Journa of Experimental Biology. 1968;6(1):55-57.

5. Mitra SK, Gopumadhavan S, Venkataranganna MV, Sarma DNK, Anturlikar SD. Uterine tonic activity of U-3107 (EveCare), a herbal preparation in rats. Indian Journal of Pharmacology. 1999;31(3):200203.

6. Murashige T, Skoog F. A revised medium for rapid growth and bioassays with tobacco tissue cultures. Physiologia Plantarum. 1962;15:473-497.

7. Jain AN, Kumar KR. In vitro propagation of critically endangered medicinal plant- Asparagus racemosus. International Journal of Pharmacy and Biological Sciences. 2013;4(3):435-448.

8. Borjian $\mathrm{L}$, Arak $\mathrm{H}$. A study on the effect of different concentration of plant hormones (BAP, NAA, 2, 4-D, and Kinetin) on callus induction in Brassica napus. International Research Journal of Applied and Basic Sciences. 2013;5(4):519-521.

9. Geier T, Anthurium. In: Evans PV, Sharp DA, Bajal YPS (eds.) Handbook of Plant Cell Culture, vol. 5. New York/London: Collier Macmillan/Macmillan; 1986:228-252.

10. Luciani GF, Mary AK, Pellegrini C, Curvetto NR. Effects of explants and growth regulators in garlic callus formation and plant regeneration. Plant Cell Tissue and Organ Culture. 2006;87:139-143.

11. Košir $P$, Škof $S$, Luthar Z. Direct shoot regeneration from nodes of Phalaenopsis orchids. Acta Agriculturae Slovenica. 2004;83(2):233-242.

12. Sharan M, Nene C, Sharon M. Regeneration of Asparagus racemosus by shoot apex and nodal explants. Asian Journal of Plant Science and Research. 2011;1(2):49-56.

13. Dharmendra, Sudarshana MS, Niranjan MH. In vitro microprapagation of Oxystelma secamone (L) Karst- A medicinal plant. Nature and Science. 2010;8(11):15-19.

14. Casado JP, Navarro MC, Utrilla MP, Jimenez J. Micropropagation of Santolina canescens Lagasca and in vitro volatiles production by shoot explants. Plant Cell Tissue and Organ Culture. 2001;69:147-153.

15. Fraternale D, Giamperi L, Ricci D, Rocchi MBL. Micropropagation of Bupleurum fruticosum: The effect of triancontanol. Plant Cell Tissue and Organ Culture. 2002;69:135-140.

16. Kar DK, Sen S. Propagation of Asparagus racemosus through tissue culture. Plant Cell Tissue and Organ Culture. 1985;5:89-95.

17. Cheetam RD, Mikloiche C, Glubiak M, Weathers P. Micropropagation of a recalcitrant male Asparagus clone (MD 22-8). Plant Cell Tissue and Organ Culture. 1992;31(1):15-19. 